\title{
Wild-type and central DNA flap defective HIV-I lentiviral vector genomes: intracellular visualization at ultrastructural resolution levels
}

\author{
Nathalie J Arhel ${ }^{\dagger 1}$, Sylvie Souquere-Besse ${ }^{\dagger 2}$ and Pierre Charneau*1
}

Address: ${ }^{1}$ Groupe de Virologie Moléculaire et Vectorologie, Institut Pasteur, 25-28 rue du Dr. Roux, 75724 Paris, France and ${ }^{2}$ Institut André Lwoff, CNRS-FRE2937, 7 rue Guy Moquet-BP8, 94800 Villejuif, France

Email: Nathalie J Arhel - arhel@pasteur.fr; Sylvie Souquere-Besse - souquere@vjf.cnrs.fr; Pierre Charneau* - charneau@pasteur.fr

* Corresponding author †Equal contributors

Published: 26 June 2006

Retrovirology 2006, 3:38 doi:10.1186/1742-4690-3-38
Received: 29 March 2006

Accepted: 26 June 2006

This article is available from: http://www.retrovirology.com/content/3/l/38

(C) 2006 Arhel et al; licensee BioMed Central Ltd.

This is an Open Access article distributed under the terms of the Creative Commons Attribution License (http://creativecommons.org/licenses/by/2.0), which permits unrestricted use, distribution, and reproduction in any medium, provided the original work is properly cited.

\begin{abstract}
HIV-I and other lentiviruses have the unique ability among retroviruses to efficiently replicate in non-dividing cells as a result of the active nuclear import of their DNA genome across an interphasic nuclear membrane. Previous work has shown that a three-stranded DNA structure synthesized during HIV-I reverse transcription, called the central DNA flap, acts as a cisdeterminant of HIV-I genome nuclear import. Concordantly, DNA Flap re-insertion in lentiviralderived gene therapy vectors stimulates gene transfer efficiencies and complements the level of nuclear import to wild-type levels quantitatively indistinguishable from wild-type virus in all cell types and tissues examined so far. In order to define the precise nature of the replicative defect of DNA flap mutant viruses, we carried out in situ DNA hybridization experiments with electron microscopy to determine the subcellular localization of DNA flap mutant and wild-type HIV-I genomes. We found that Flap defective DNA genomes accumulate at the cytoplasmic face of the nuclear membrane with no overlap across the nuclear membrane, whereas wild-type genomes localize throughout the nuclear compartment. These data provide an unequivocal confirmation of the role of the DNA flap in HIV-I nuclear import and further establish that the DNA flap controls a step that immediately precedes translocation through the nuclear pore. Further, the widespread distribution of wild-type genomes within the open chromatin confirms the recent genome-wide mapping of HIV-I cDNA integration sites and points to an as-yet poorly understood step of intranuclear transport of HIV-I pre-integration complexes.
\end{abstract}

\section{Findings}

HIV-1 and other lentiviruses have evolved a more complex reverse transcription strategy than oncoviruses whereby the presence of two additional cis-acting sequences within the lentiviral genome, the central polypurine tract (CPPT) and the central termination sequence (CTS), leads to the formation of a three-stranded DNA structure called the central DNA Flap [1-3]. Mutations within the cPPT lead to a linear genome lacking the central DNA Flap and severely impair viral replication $[2,4]$. While wild-type viral DNA is almost entirely imported into the nucleus where it either integrates or circularizes, DNA Flap defective viral DNA accumulates as unintegrated linear DNA as a consequence of a lack of access to the nuclear compartment, indicating a defect in nuclear import [4]. 
Table I: Sequential experimental steps for in situ hybridization

\begin{tabular}{|c|c|c|c|c|c|}
\hline Step & Material & Concentration & Buffer & Duration & Temperature \\
\hline Fixation & Paraformaldehyde & $4 \%$ & Sörensen & $\mathrm{l} h r$ & $4^{\circ} \mathrm{C}$ \\
\hline Lowicryl embedding & & & & 5 days & $-30^{\circ} \mathrm{C}$ \\
\hline \multicolumn{6}{|l|}{ Sectioning (gold grids) } \\
\hline \multirow[t]{2}{*}{ Enzymatic digestion } & Protease $\mathrm{a}^{\mathrm{a}}$ & $0.2 \mathrm{mg} / \mathrm{ml}$ & Distilled water & $15 \mathrm{~min}$ & $37^{\circ} \mathrm{C}$ \\
\hline & RNase $A^{b}$ & $\mathrm{l} \mathrm{mg} / \mathrm{ml}$ & Tris $\mathrm{HCl}, 10 \mathrm{mM}, \mathrm{pH} 7.3$ & $\mathrm{I} h r$ & $37^{\circ} \mathrm{C}$ \\
\hline Denaturation of grid target DNA & $\mathrm{NaOH}$ & $0.5 \mathrm{~N}$ & Distilled water & $4 \mathrm{~min}$ & $R T^{d}$ \\
\hline Denaturation of hybridization solution & & & & $4 \min$ & $95^{\circ} \mathrm{C}$ \\
\hline Hybridization & & & & $\mathrm{o} / \mathrm{n}^{\mathrm{c}}$ & $37^{\circ} \mathrm{C}$ \\
\hline Detection of hybrids & Anti-biotin $10 \mathrm{~nm}$ gold conjugate & $\mathrm{I}: 25$ & PBS & $30 \mathrm{~min}$ & $R T^{d}$ \\
\hline
\end{tabular}

a The aim of this step is to eliminate proteins within the section which could otherwise interfere with binding of the probe to the target DNA. $b$ The aim of this step is to eliminate all RNA molecules including viral RNA to prevent their concomittant detection with viral DNA. c Overnight. ${ }^{d}$ Room temperature

Consistently with the cis-acting role of the central DNA Flap in HIV-1 genome nuclear import, its reinsertion in HIV-1 derived gene transfer vectors can complement the level of nuclear import from a strong defect to wild-type nuclear import levels, quantitatively indistinguishable from wild-type virus [4]. As a result, DNA Flap containing lentiviral vectors closely mimic the early steps of wild-type virus infection. Reinsertion of the DNA Flap in HIV-1 vectors stimulated gene transfer efficiencies both in vivo and ex vivo in all tissue- and cell-types examined [5-14], thus making the DNA Flap an essential and widely-used component of lentiviral gene therapy vectors.

In an effort to elucidate the mechanistic implication of the central DNA Flap in HIV-1 nuclear import, we sought to precisely characterize the nature of the nuclear import defect of DNA Flap mutant viruses. We previously found, using subcellular fractionation experiments together with localization of viral DNA by fluorescence in situ hybridization (FISH) that central DNA Flap defective molecules accumulate at close proximity to the nuclear compartment indicating a late defect in nuclear import following a normal and rapid routing process of viral complexes from the plasma membrane to the nuclear membrane [4]. However, the precise nature of the nuclear import replicative defect, such as translocation through the nuclear pore or any step that immediately precedes or follows translocation, was not known.

We therefore sought to define with ultrastructural resolution the subcellular compartment of accumulation of Flap+ versus Flap- HIV-1 genomes. We carried out in situ DNA hybridization with electron microscopy on MT4 cells transduced with HIV-1 derived vectors, including or not the central DNA Flap. MT4 cells are HTLV-1 transformed human CD4+ T lymphocytes, maintained in RPMI 1640 medium supplemented with 10\% FCS. MT4 cells are highly permissive to transduction, while vectors benefit from higher titers compared to viruses, thus opti- mizing the detection of vector DNA within cell sections. In addition, the use of HIV-1 replication defective vectors enabled us to limit our observations to one-round transduction events. The HIV-1 vector HR, derived from HR'CMVLacZ [15], does not contain the cis-acting sequences required for formation of the central DNA Flap. The HIV-1 vector TRIP is identical to HR but with the DNA Flap sequences reinserted within the vector sequence. HIV-1 vectors were produced as previously described [15]. Carry-over DNA in the vector supernatants was eliminated by treating the vector stocks with DNase I $(1 \mu \mathrm{g} / \mathrm{ml}$ in the presence of $1 \mu \mathrm{M} \mathrm{MgCl}_{2}$ ) for $15 \mathrm{~min}$ at $37^{\circ} \mathrm{C}$.

MT4 lymphocytes were transduced with the TRIP Flap+ or HR Flap- vector, with a multiplicity of infection of 100 , as determined from the number of copies of provirus per cell by quantitative PCR (a high MOI is required for viral DNA detection by in situ DNA hybridization with electron microscopy). At $48 \mathrm{hr}$ post-transduction, a time point when most incoming complexes, in the context of a highly asynchronous infection, have completed the entire early steps phase and have reached their final state [4], transduced and non-transduced cells were fixed in $4 \%$ formaldehyde (Merck) in $0.1 \mathrm{M}$ Sörensen's phosphate buffer, $\mathrm{pH} \mathrm{7.3,} \mathrm{at} 4^{\circ} \mathrm{C}$ for $1 \mathrm{hr}$. These were then dehydrated in methanol and embedded at low temperature in Lowicryl K4M (Polysciences Europe, Germany). Polymerization was carried out under long wavelengh UV light at $-30^{\circ} \mathrm{C}$. Ultrathin sections were collected onto carbon-Formvarcoated gold grids (200 mesh). In situ DNA hybridization was carried out as previously described [16] using a biotinylated double-stranded vector specific DNA probe [4] (please refer to Additional file 1 for a detailed protocol for HIV-1 DNA genome detection by in situ DNA hybridization and electron microscopy). Prior to hybridization the grids underwent a series of successive enzymatic and denaturation treatments (Table 1): bacterial protease type VI (Sigma, St Louis, MO/USA) to render the DNA accessible to the probe, RNase A (BDH Biochemical Ltd, UK) to 
eliminate RNA sequences including those that are homologous to the probe, $\mathrm{NaOH}$ treatment to denature the DNA present in the sections, and heat treatment to denature the double-stranded DNA probe. Vector DNA-probe hybrids were detected within $90 \mathrm{~nm}$ thick sections by direct immunogold labeling using anti-biotin conjugated $10 \mathrm{~nm}$ colloidal gold particles (British Biocell International) diluted 1/25 in PBS, for $30 \mathrm{~min}$ at room temperature. Grids were stained with uranyl acetate prior to observation. The specificity of the hybridization signals was confirmed by negative results following additional DNase I treatment of sections prior to hybridization $(1 \mathrm{mg} / \mathrm{ml}$, Worthington Biochem. Corp.) at $37^{\circ} \mathrm{C}$ for $1 \mathrm{hr}$ (data not shown), and in situ DNA hybridization of non-transduced cells (Figure 3A). Samples were observed with a Philips 400 electron microscope at $80 \mathrm{kV}$.

The images that we show were taken from 4 independent cell population infections and inclusions, and 25 hybridization experiments. In every experiment, each electron transmission grid contained 5 sample slices, each of which contained 10-20 cell sections. Therefore, approximately 1,250 to 2,500 cells were observed for the purpose of this study. In the context of HIV infection, detection by in situ DNA hybridization and immuno-gold staining is a rare event, even when using a permissive target cell such as MT4 and high multiplicity of infection. As a result, about $5-10 \%$ of cells observed actually contained DNA hybridization signal. Importantly, all cell areas containing DNA hybridization signal were systematically photographed (about 150-200 photos). Observations were carried out in single-blind conditions, and images shown are highly representative of all data obtained.

We found that wild-type vector DNA including the DNA Flap accumulates predominantly within the nucleus of transduced cells $48 \mathrm{hr}$ post-transduction, and more specifically within open regions of the chromatin (Figure 1). The detection of vector DNA hybridization signals does not discriminate between integrated proviruses and DNA circles, therefore intranuclear signals do not all necessarily correspond to actively transcribed genomes. At $48 \mathrm{hr}$ posttransduction, previous DNA profile analyses showed that $\sim 55 \%$ of nuclear localized genomes are integrated proviruses, the rest being one-long terminal repeat (LTR) DNA circles and few 2-LTR circles [4].

DNA Flap defective viral genomes, on the other hand, accumulate predominantly on the cytoplasmic face of the nuclear membrane (Figure 2), confirming a nuclear import defect of Flap defective pre-integration complexes that does not implicate the routing process from the plasma membrane to the nucleus. As previously shown, there is no degradation of this cytoplasmic linear unintegrated viral DNA between 12 and 48 hr post-transduction
[4]. Importantly here, DNA hybridization signals remain on the cytoplasmic side of the nuclear membrane, with no overlap across the nuclear membrane, revealing that Flap defective DNA molecules have not initiated translocation through the nuclear pore. Non-transduced control samples exhibited negligible background signal (Figure 3A). Precise quantification of DNA hybridization signals $48 \mathrm{hr}$ post-transduction on randomly selected micrographs (Figure 3B) revealed a strong accumulation of nuclear versus cytoplasmic vector DNA in the case of DNA Flap+ vector with an average nuclear/cytoplasmic ratio of $3.9 \pm 0.9$, which means that $77.3 \pm 3.6 \%$ of total vector DNA was detected within the nuclear compartment. Conversely, there was a strong accumulation of cytoplasmic versus nuclear vector DNA in the case of DNA Flap- vector with an average nuclear/cytoplasmic ratio of $0.2 \pm 0.04$, which corresponds to $86.4 \pm 2.8 \%$ of total vector DNA being detected in the cytoplasm. Results are highly statistically significant ( $\mathrm{p}<0.0001$, Mann-Whitney test) and consistent with published intracellular vector DNA profiles assessed by quantitative Southern blotting [4].

This is, to our knowledge, the first report of the intracellular visualization of HIV-1 DNA genomes by in situ DNA hybridization with electron microscopy. The data we obtained reveal that lack of the central DNA Flap results in perinuclear accumulation of viral genomes that do not overlap across the nuclear membrane, indicating a defect preceding translocation of pre-integration complexes through the nuclear pore. Of note and as we previously reported [4], absence of the central DNA Flap does not entirely preclude HIV-1 genome nuclear import. The 10$20 \%$ of Flap- genomes that are imported into the nucleus points to a Flap-independent nuclear import mechanism that likely accounts for transduction levels obtained with Flap- vectors, a current area of investigation in our laboratory.

The search for the viral determinants responsible for the active nuclear import of the HIV-1 DNA genome has constituted an active but controversial field of investigation. Based on the search of a sequence that obeys the consensus for nuclear localization, three HIV-1 proteins, MA, Vpr and IN, have been proposed to contribute in a redundant manner to the karyophilic properties of the HIV-1 preintegration complex [[17-19], among others]. However, the actual participation of these proteins in HIV-1 genome nuclear import is a matter of strong debate [[20-23], among others]. The implication of the central DNA Flap in HIV-1 nuclear import has also been questioned in two reports $[24,25]$ that suggested the central DNA Flap, while important in the context of HIV-1 derived vectors, not to be essential for HIV-1 replication. However, detailed analyses of virus infectivity revealed that all CPPT mutant viruses exhibit reduced infectivity and defective nuclear 

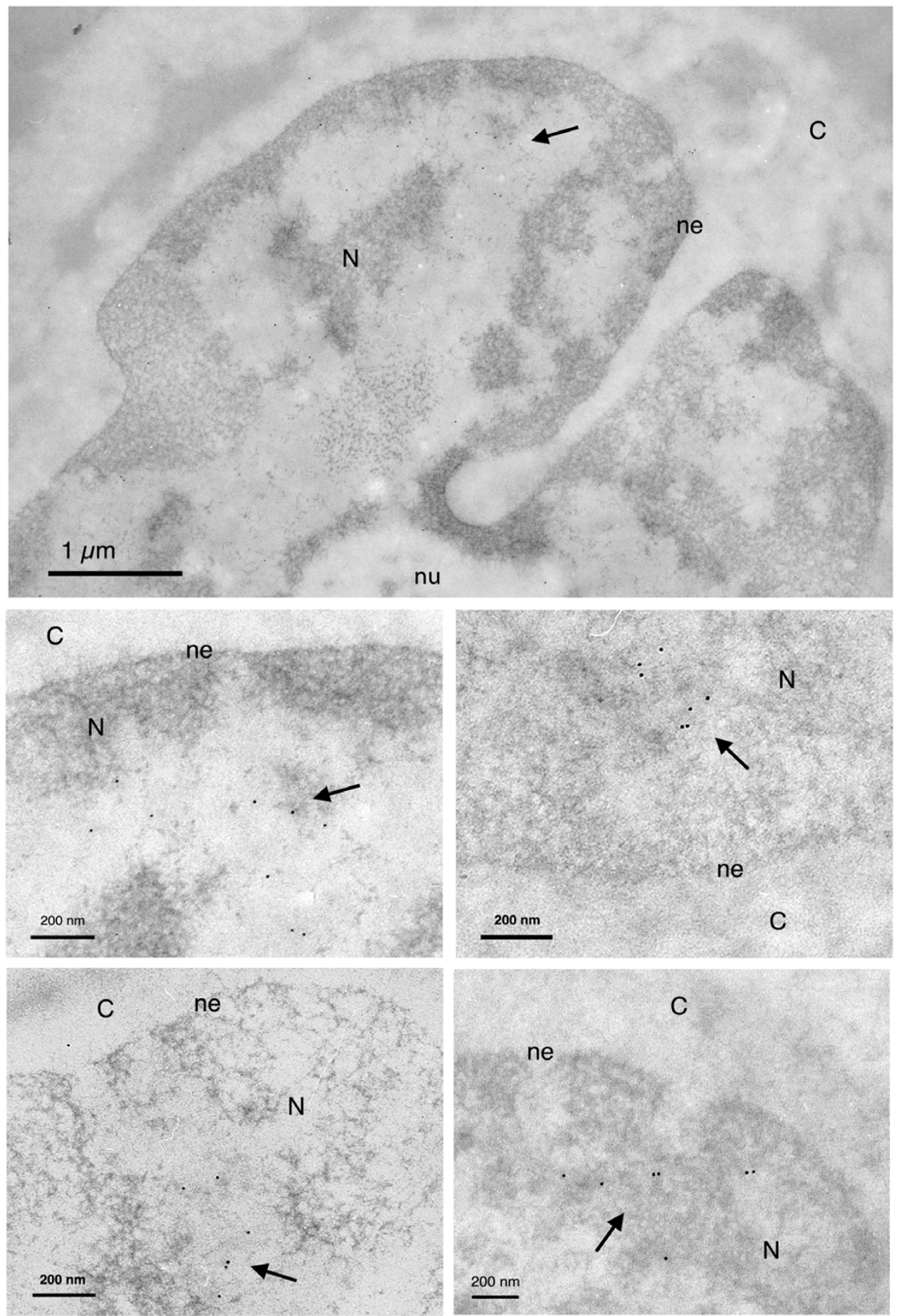

\section{Figure I}

Ultrastructural subcellular localization of HIV-I derived vector genomes including the central DNA Flap (Flap +). Electron micrographs showing MT4 cells $48 \mathrm{hr}$ following transduction with the TRIP Flap+ vector. Vector DNA genomes including the DNA Flap are found predominantly within the nucleus. $\mathrm{N}=$ nucleus; ne = nuclear envelope; nu = nucleolus; $\mathrm{C}=$ cytoplasm. Images show one low and four high magnification micrographs. The first high magnification micrograph is an enlargement from the low magnification image. The other three are taken from other independent experiments. All are highly representative of the data obtained. Arrows point to clusters of immunogold labeled vector DNA. 

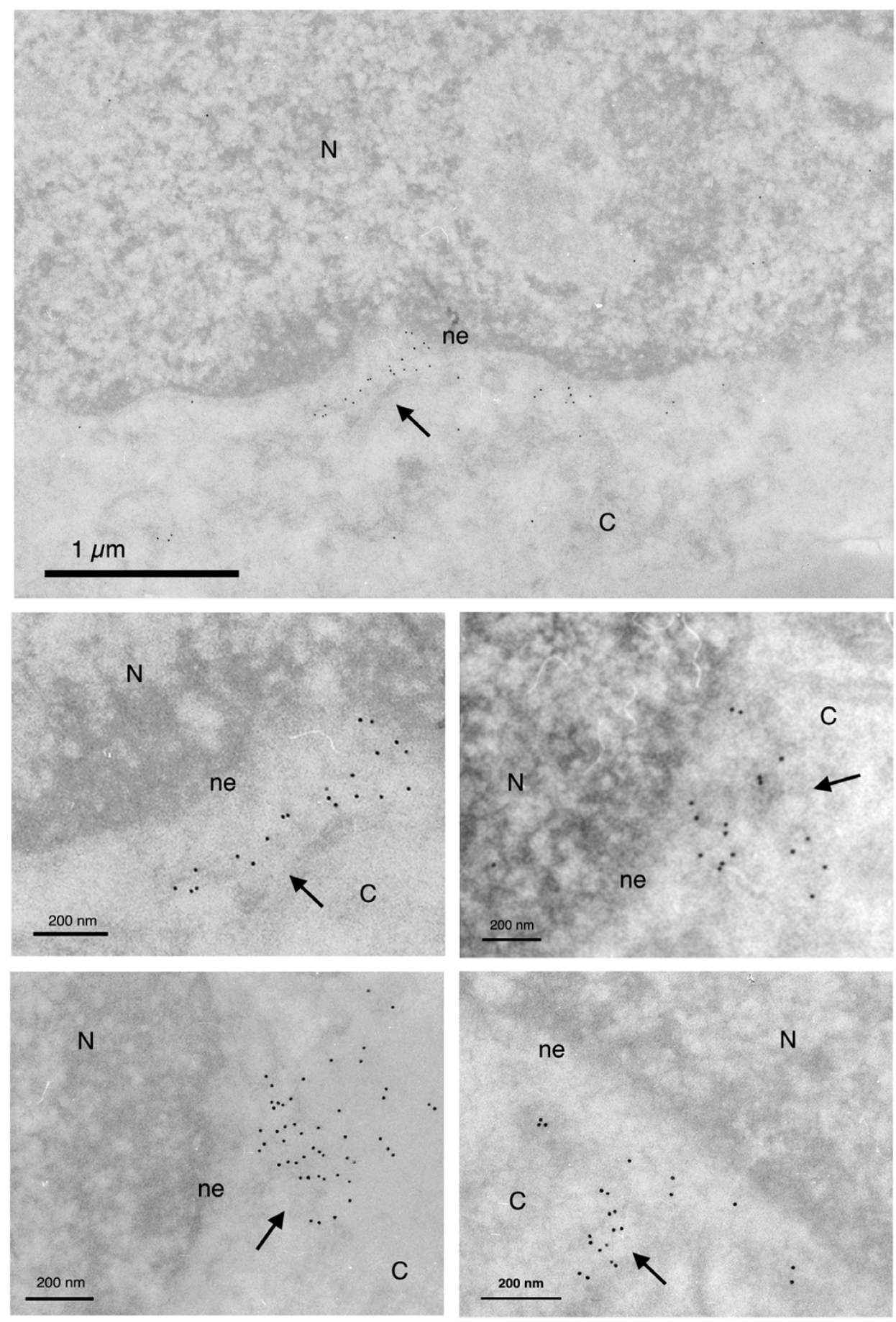

Figure 2

Ultrastructural subcellular localization of HIV-I derived vector genomes without the central DNA Flap (Flap ). MT4 cells $48 \mathrm{hr}$ post-transduction with the HR Flap- vector. DNA Flap defective vector genomes localize on the cytoplasmic side of the nuclear membrane. $\mathrm{N}=$ nucleus; ne = nuclear envelope; $\mathrm{C}=$ cytoplasm. Images show one low and four high magnification micrographs. The first high magnification micrograph is an enlargement from the low magnification image. The other three are taken from other independent experiments. All are highly representative of the data obtained. Arrows point to clusters of immunogold labeled vector DNA. 
A

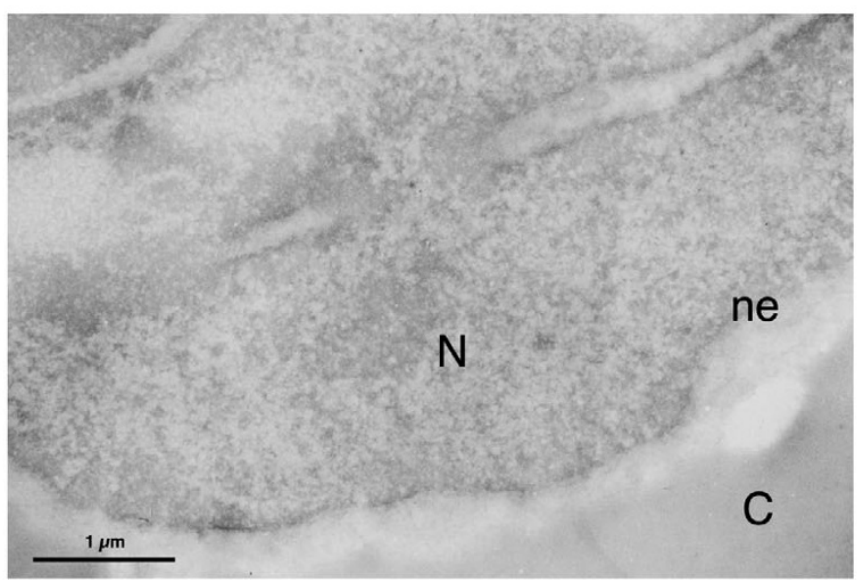

B

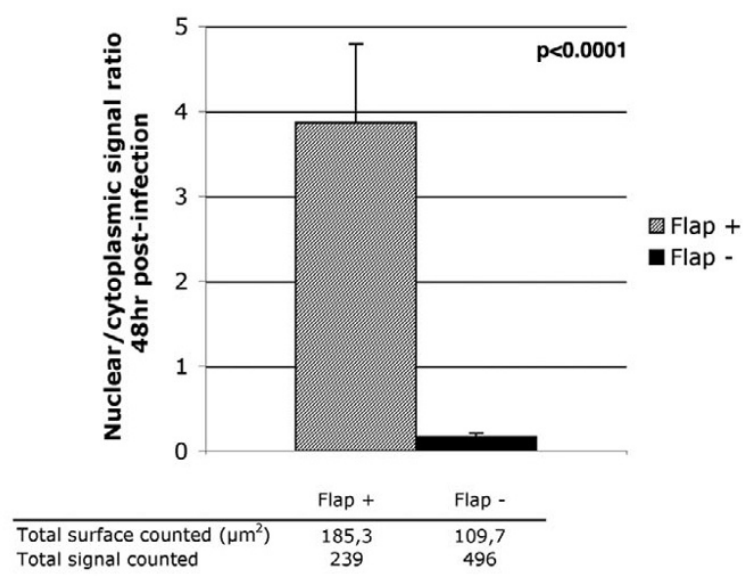

\section{Figure 3}

Quantification of intracellular vector genome detection. (A) Electron micrograph of control non-transduced cells showing minimal background signal. (B) DNA hybridization signals from 4 independent cell population infections were counted and represented as total nuclear over cytoplasmic signal ratio. All cell areas containing DNA hybridization signal were systematically photographed (about 150-200 photos) and signal was carefully quantified, each time with equal surface of nuclear and cytoplasmic compartments. The $p$ value (Mann-Whitney test) shows the results are highly statistically relevant.

import irrespective of the viral genetic background or target cells (manuscript submitted). Here, the ultrastrucutral localization of Flap defective molecules confirms that the central DNA Flap is a cis-acting DNA motif that is implicated in HIV-1 nuclear import. The inhibition of nuclear import in the absence of this motif, although not absolute, points to a mechanistic implication of the DNA Flap in a step immediately prior to translocation of the viral genome through the nuclear pore. Other viral factors, and conceivably many cellular factors, are also expected to contribute to the active nuclear import of HIV-1.

In the case of Flap+ vector genomes, hybridization signals were detected predominantly within the open regions of the chromatin, confirming previous work showing preferential integration of HIV-1 within actively transcribed genes [26-28]. Moreover, signals are visualized throughout the nuclear compartment, without particular preference for areas close to the nuclear membrane, indicating probable intranuclear transport events of HIV-1 DNA genomes after translocation through the nuclear membrane and until the integration sites are reached. This concurs with the recent HIV-1 integration site mapping showing integration throughout the genome [26]. The nature and mechanisms of this intranuclear transport remain entirely to be characterized.

\section{Competing interests}

The author(s) declare that they have no competing interests.

\section{Authors' contributions}

NJA prepared the infected samples, participated in the design of the study, performed the statistical analysis, and drafted the manuscript. SSB carried out all hybridizations and electron microscopy observations in a single blind fashion, and contributed to the statistical analysis. PC conceived and coordinated the study and drafted the manuscript. All authors read and approved the final manuscript.

\section{Additional material}

\section{Additional File 1}

Detailed protocol for HIV-1 DNA genome detection by in situ DNA hybridization and electron microscopy.

Click here for file

[http://www.biomedcentral.com/content/supplementary/1742-

4690-3-38-S1.doc]

\section{Acknowledgements}

Many thanks are extended to Renan Duprez for his help with the statistical analyses. 


\section{References}

I. Charneau P, Clavel F: A single-stranded gap in human immunodeficiency virus unintegrated linear DNA defined by a central copy of the polypurine tract. J Virol 1991, 65:24I5-242I.

2. Charneau $P$, Alizon M, Clavel F: A second origin of DNA plusstrand synthesis is required for optimal human immunodeficiency virus replication. J Virol 1992, 66:28|4-2820.

3. Charneau P, Mirambeau G, Roux P, Paulous S, Buc H, Clavel F: HIVI reverse transcription. A termination step at the center of the genome. J Mol Biol 1994, 241:651-662.

4. Zennou V, Petit C, Guetard D, Nerhbass U, Montagnier L, Charneau P: HIV-I genome nuclear import is mediated by a central DNA Flap. Cell 2000, I 01:173-185.

5. Sirven A, Pflumio F, Zennou V, Titeux M, Vainchenker W, Coulombel L, Dubart-Kupperschmitt A, Charneau P: The human immunodeficiency virus type-I central DNA Flap is a crucial determinant for lentiviral vector nuclear import and gene transduction of human hematopoietic stem cells. Blood 2000 , 96:4103-4II0.

6. Follenzi A, Ailles LE, Bakovic S, Geuna M, Naldini L: Gene transfer by lentiviral vectors is limited by nuclear translocation and rescued by HIV-I pol sequences. Nat Genet 2000, 25:2 17-222.

7. Dardalhon V, Herpers B, Noraz N, Pflumio F, Guetard D, Leveau C, Dubart-Kupperschmitt A, Charneau P, Taylor N: Lentivirus-mediated gene transfer in primary $T$ cells is enhanced by a central DNA Flap. Gene Ther 2001, 8:190-198.

8. Park F, Kay MA: Modified HIV-I based lentiviral vectors have an effect on viral transduction efficiency and gene expression in vitro and in vivo. Mol Ther 200I, 4:164-I73.

9. Zennou V, Serguera C, Sarkis C, Colin P, Perret E, Mallet J, Charneau P: The HIV-I DNA Flap stimulates HIV vector-mediated cell transduction in the brain. Nat Biotechnol 200I, 19:446-50.

10. Yam PY, Li S, Wu J, Hu J, Zaia JA, Yee JK: Design of HIV vectors for efficient gene delivery into human hematopoietic cells. Mol Ther 2002, 5:479-484.

I I. Nguyen TH, Oberholzer J, Birraux J, Majno P, Morel P, Trono D: Highly efficient lentiviral vector-mediated transduction of nondividing, fully reimplantable primary hepatocytes. Mol Ther 2002, 6:199-209.

12. Van Maele B, De Rijck J, De Clercq E, Debyser Z: Impact of the central polypurine tract on the kinetics of human immunodeficiency virus type I vector transduction. J Virol 2003, 77:4685-4694.

13. Giannini C, Morosan S, Tralhao JG, Guidotti JE, Battaglia S, Mollier K, Hannoun L, Kremsdorf D, Gilgenkrantz H, Charneau P: A highly efficient, stable, and rapid approach for ex vivo human liver gene therapy via a FLAP lentiviral vector. Hepatology 2003, 38: II4-I22.

14. Breckpot K, Dullaers M, Bonehill A, van Meirvenne S, Heirman C, de Greef C, van der Bruggen P, Thielemans K: Lentivirally transduced dendritic cells as a tool for cancer immunotherapy. I Gene Med 2003, 5:654-667.

15. Naldini L, Blomer U, Gallay P, Ory D, Mulligan R, Gage FH, Verma IM, Trono D: In vivo gene delivery and stable transduction of nondividing cells by a lentiviral vector. Science 1996, 272:263-267.

16. Puvion-Dutilleul F, Besse S, Pichard E, Cajean-Feroldi C: Release of viruses and viral DNA from nucleus to cytoplasm of HeLa cells at late stages of productive adenovirus infection as revealed by electron microscope in situ hybridization. Biol Cell 1998, 90:5-38.

17. Bukrinsky MI, Haggerty S, Dempsey MP, Sharova N, Adzhubel A, Spitz L, Lewis P, Goldfarb D, Emerman M, Stevenson M: A nuclear localization signal within HIV-I matrix protein that governs infection of non-dividing cells. Nature 1993, 365:666-669.

18. Heinzinger NK, Bukinsky MI, Haggerty SA, Ragland AM, Kewalramani V, Lee MA, Gendelman HE, Ratner L, Stevenson M, Emerman M: The Vpr protein of human immunodeficiency virus type I influences nuclear localization of viral nucleic acids in nondividing host cells. Proc Natl Acad Sci USA 1994, 91:73 I I-73 I5.

19. Gallay P, Swingler S, Song J, Bushman F, Trono D: HIV nuclear import is governed by the phosphotyrosine-mediated binding of matrix to the core domain of integrase. Cell 1995, 83:569-576.

20. Freed EO, Martin MA: HIV-I infection of non-dividing cells. Nature 1994, 369:107-108.
21. Freed EO, Englund G, Maldarelli F, Martin MA: Phosphorylation of residue I 3 I of HIV-I matrix is not required for macrophage infection. Cell 1997, 88: I7I-I73.

22. Petit C, Schwartz O, Mammano F: The karyophilic properties of human immunodeficiency virus type $I$ integrase are not required for nuclear import of proviral DNA. J Virol 2000, 74:7II9-7I26.

23. Limon A, Devroe E, Lu R, Ghory HZ, Silver PA, Engelman A: Nuclear localization of human immunodeficiency virus type I preintegration complexes (PICs): VI65A and RI66A are pleiotropic integrase mutants primarily defective for integration, not PIC nuclear import. J Virol 2002, 76: I0598-10607.

24. Dvorin JD, Bell P, Maul GG, Yamashita M, Emerman M, Malim MH: Reassessment of the roles of integrase and the central DNA flap in human immunodeficiency virus type I nuclear import. J Virol 2002, 76: I 2087-I2096.

25. Limon A, Nakajima N, Lu R, Ghory HZ, Engelman A: Wild-type levels of nuclear localization and human immunodeficiency virus type I replication in the absence of the central DNA flap. J Virol 2002, 76: | 2078- I 2086.

26. Schroder AR, Shinn P, Chen H, Berry C, Ecker JR, Bushman F: HIV$I$ integration in the human genome favors active genes and local hotspots. Cell 2002, I 1 0:52 I-529.

27. $\mathrm{Wu} \mathrm{X}, \mathrm{Li} Y$, Crise B, Burgess SM: Transcription start regions in the human genome are favored targets for MLV integration. Science 2003, 300: |749-175।.

28. Mitchell RS, Beitzel BF, Schroder AR, Shinn P, Chen H, Berry CC, Ecker J, Bushman FD: Retroviral DNA integration: ASLV, HIV, and MLV show distinct target site preferences. PLoS Biol 2004, 2: I 1 27-37.
Publish with Bio Med Central and every scientist can read your work free of charge

"BioMed Central will be the most significant development for disseminating the results of biomedical research in our lifetime. "

Sir Paul Nurse, Cancer Research UK

Your research papers will be:

- available free of charge to the entire biomedical community

- peer reviewed and published immediately upon acceptance

- cited in PubMed and archived on PubMed Central

- yours - you keep the copyright 